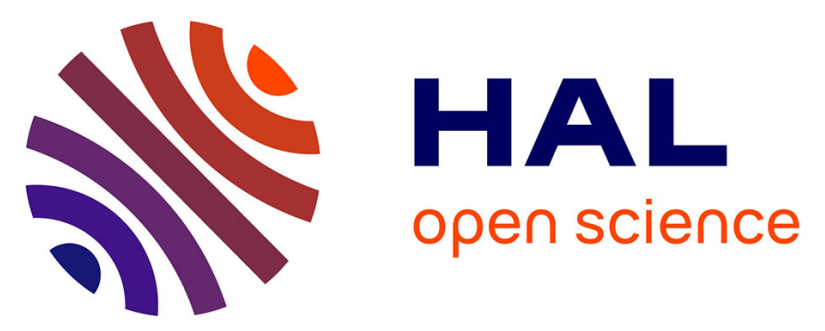

\title{
Patterns of Knowledge Outflow from Industrial Marketing Management to Major Marketing and Specialized Journals (1999-2013): A Citation Analysis
}

Anthony Di Benedetto, Shikhar Sarin, Mustapha Belkhouja, Christophe Haon

\section{- To cite this version:}

Anthony Di Benedetto, Shikhar Sarin, Mustapha Belkhouja, Christophe Haon. Patterns of Knowledge Outflow from Industrial Marketing Management to Major Marketing and Specialized Journals (19992013): A Citation Analysis. Industrial Marketing Management, 2018, 69, pp.13-17. halshs-01786865

\section{HAL Id: halshs-01786865 \\ https://shs.hal.science/halshs-01786865}

Submitted on 7 May 2018

HAL is a multi-disciplinary open access archive for the deposit and dissemination of scientific research documents, whether they are published or not. The documents may come from teaching and research institutions in France or abroad, or from public or private research centers.
L'archive ouverte pluridisciplinaire HAL, est destinée au dépôt et à la diffusion de documents scientifiques de niveau recherche, publiés ou non, émanant des établissements d'enseignement et de recherche français ou étrangers, des laboratoires publics ou privés. 


\title{
Patterns of Knowledge Outflow from Industrial Marketing Management to Major Marketing and Specialized Journals (1999-2013): A Citation Analysis
}

\author{
Anthony Di Benedetto \\ Professor of Marketing and Senior Washburn Research Fellow \\ Fox School of Business \\ Temple University \\ Philadelphia, PA 19122 \\ Phone: (215) 204-8147 \\ E-mail: tonyd@ @emple.edu \\ Shikhar Sarin \\ Professor of Marketing \\ Boise State University \\ Boise, ID 83712 U.S.A. \\ Phone: (208) 426-2732 \\ E-mail: ssarin@boisestate.edu \\ Mustapha Belkhouja \\ Assistant Professor \\ Grenoble Ecole de Management \\ Grenoble, France \\ Phone: \\ E-mail: Mustapha.Belkhouja@grenoble-em.com \\ Christophe Haon \\ Professor of Marketing \\ Grenoble Ecole de Management \\ Grenoble, France \\ Phone: +44 476706516 \\ E-mail: christophe.haon@grenoble-em.com
}

The authors would like to thank Vincent Mangematin for providing access to the data. 


\section{Patterns of Knowledge Outflow from Industrial Marketing Management to Major Marketing and Specialized Journals (1999-2013): A Citation Analysis}

\section{Introduction}

Journals often mark special, commemorative occasions and major milestones by engaging in healthy introspective evaluations of their history, strategy, evolution, and impact (e.g., Schrock et al. 2016; Huber, Kamakura and Mela 2014; Hustad 2013; Chintagunta et al. 2013; Calabretta, Durisin and Ogiliengo 2011). In this rich tradition, we mark the changing of the guard at Industrial Marketing Management, and Peter Laplaca's long tenure as Editor of IMM by tracing the impact Industrial Marketing Management has had on major marketing and specialized B2B marketing journals from 1999-2013. This period of interest overlaps significantly with Peter's stewardship of the journal.

Recent studies have examined levels of citation flows to assess import and export of knowledge between disciplines and domains (e.g. Clark et al. 2014; Shafiq 2013). We use a similar approach, but at the level of a particular journal. Specifically, we take a dynamic, yearby-year look at the impact Industrial Marketing Management (IMM) has had in terms of its Impact Factor, and citations in relevant major marketing and journals focusing on industrial/business-to-business marketing. In particular, from 1999-2013 we take a longitudinal look at:

1) the level of self-citation by IMM, and the growth in its impact factor;

2) the level of citation of IMM by top tier marketing journals;

3) the level of citation of IMM by second tier marketing journals, and specialized $\mathrm{B} 2 \mathrm{~B} /$ industrial marketing journals; and

4) the effect of self- and cross-citations on the 2-year Impact Factor of IMM from 19992013. 


\section{Data}

We extracted article-by-article citation data from 336 journals in major business disciplines from the Web of Science from 1999 to 2013. This bibliometric database contained data on 5,390,245 citations from $116,750 \operatorname{articles}^{1}$. For the purpose of this essay, we narrowed the analysis down to a list of top-tier and second-tier marketing journals as identified by Guidry et al (2004) based on citation analysis. The Top 5 marketing journals included: Journal of Marketing (JM), Journal of Marketing Research (JMR), Journal of Consumer Research (JCR), Marketing Science (MKSC), and Journal of the Academy of Marketing Science (JAMS).

The next five (second tier) marketing journals as identified by Guidry et al (2004) were: Journal of Retailing (JR), Journal of Business Research (JBR), Marketing Letters (ML), International Journal of Research in Marketing (IJRM), and Journal of Product Innovation Management (JPIM) ${ }^{2}$. To this set of top and second tier marketing journals, we added two specialized journals with specific relevance to business marketing and B2B marketing: Journal of Business to Business Marketing (JBBM) and Journal of Business and Industrial Marketing $(\mathrm{JBIM})^{34}$. The final analyses were based on 436,943 citations from 8767 articles published in these 13 journals (the 12 above mentioned journals and Industrial Marketing Management) over a 15-year period (1999-2013). A total of 1,944 of these articles cited IMM 8,065 times over this period.

\footnotetext{
${ }^{1}$ Not all the journal records included in this database started in 1999. Some of the journals were incorporated in the database at later dates.

${ }^{2}$ Journal of Advertising Research was tied with JPIM in Guidry et al (2004) ranking, but it was excluded from this analysis because of its lack of relevance to industrial/business marketing.

${ }^{3}$ Data for these two journals were only available from 2005-2013 in the database.

${ }^{4}$ While the Journal of Personal Selling and Sales Management (JPSSM) would also have been of interest in the specialized journals, we unfortunately did not have data on JPSSM in the database.
} 


\section{IMM's Impact Factor, Self-and Cross-Citation Rates in Top Tier, Second Tier and Specialized Marketing Journals (1999 - 2013)}

The journals under consideration differ with respect to the number of issues published per year, the number of articles published per issue, and the number of references cited per article. In order to account for these differences, all citation data were normalized, and are presented here in terms of the percentage of all references cited in that journal in that year.

Figure 1 presents the change in the 2-year impact factor of IMM along with its selfcitation rates from 1999-2013. After decreasing from 1999 to 2006, the self-citation rates grew consistently, reaching nearly $11 \%$ in 2013 . All this while, the 2 -year impact factor of the journal increased steadily from 1999-2013. Figure 2 shows the growth in IMM's 2-year impact factor relative to its cross-citations in the top-tier, and second-tier and specialized B2B marketing journals. The figure shows that IMM's citations in top-tier marketing journals remains consistently low over the 15-year period under examination. However, the impact factor of the journals tracks the citations in second-tier and specialized B2B marketing journals quite well over this period.

Next, we examined the effect of self- and cross-citation (top tier, second tier and specialized marketing journals) rates on the 2-year impact factor of IMM. Table 1 presents the descriptive statistics and correlations between the variables. 
Figure 1 - IMM Self-Citation Rate and Impact Factor (1999-2013)

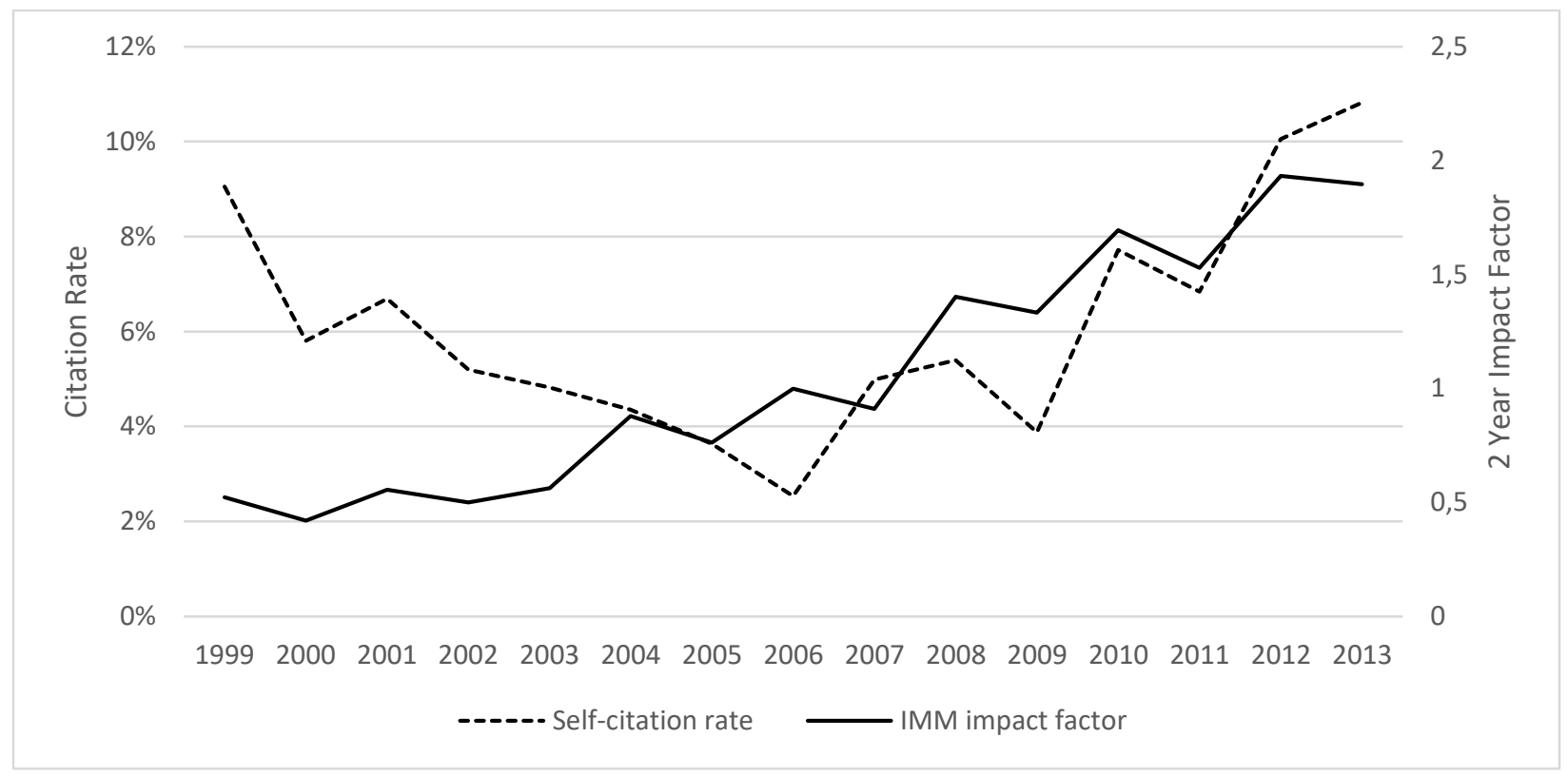

Figure 2 - IMM Impact Factor and Cross-Citation Rates (Top-Tier, Second Tier and Specialized B2B Marketing Journals) (1999-2013)

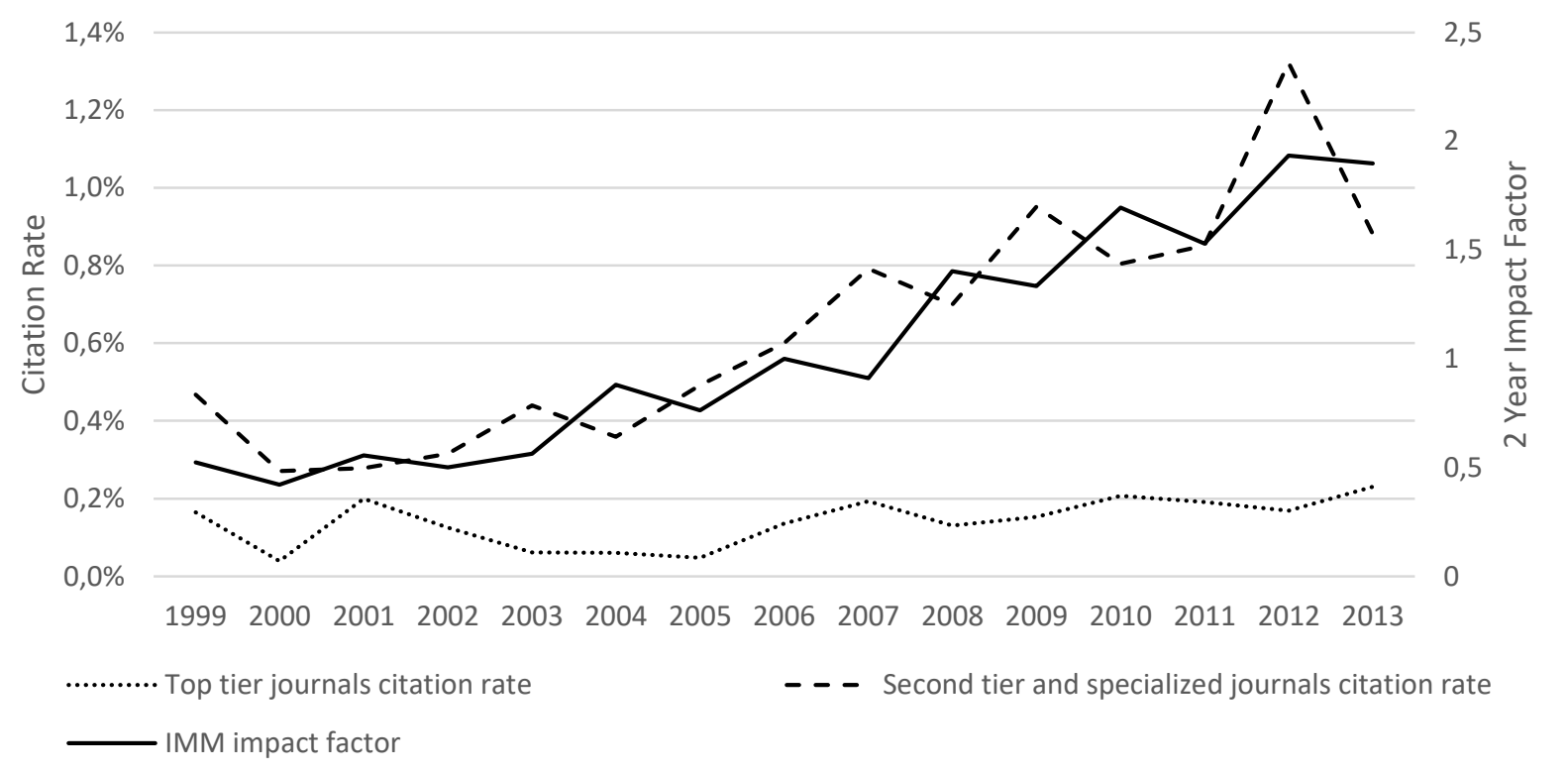


Table 1 - Descriptive Statistics and Correlation Matrix

\begin{tabular}{|c|c|c|c|c|c|c|}
\hline & \multirow[t]{2}{*}{ Mean } & \multirow[t]{2}{*}{ S.D. } & \multicolumn{4}{|c|}{ Correlations } \\
\hline & & & 1 & 2 & 3 & 4 \\
\hline 1 IMM impact factor & 1.0604 & 5302 & 1.00 & & & \\
\hline 2 IMM self-citation & .0611 & .024 & $.49^{*}$ & 1.00 & & \\
\hline 3 Citations in top tier marketing journals & 0014 & .0006 & $.58^{* *}$ & $.59^{* *}$ & 1.00 & \\
\hline $\begin{array}{l}4 \text { Citations in second tier and specialized } \\
\text { marketing journals }\end{array}$ & .0063 & .003 & $.88^{* * * *}$ & .42 & $.54^{* * *}$ & 1.00 \\
\hline
\end{tabular}

The correlation matrix shows only a weak positive correlation between IMM self-citation and it 2-year impact factor $(\mathrm{r}=.49 ; \mathrm{p}<.10)$. This is could be because the relationship between the two may not be strictly linear (see Figure 1). IMM self-citations, on the other hand, were strongly correlated with citations in second-tier and specialized B2B marketing journals $(\mathrm{r}=.88$; $\mathrm{p}<.01$ ). Top-tier marketing journals have a significant and positive correlation with both IMM self-citation $(\mathrm{r}=.59 ; \mathrm{p}<.05)$ and citations in second tier and specialized marketing journals $(\mathrm{r}=$ $.54 ; \mathrm{p}<.05)$.IMM self-citation and second tier and specialized marketing journals' citations were not significantly correlated.

In order to further ascertain the effect of citation rates on impact factors, we regressed IMM's 2-year impact factor on self- and cross-citation rates (top-tier, second-tier and specialized B2B marketing journals) over the 1999-2013 period. Table 2 reports the results of this multiple regression analysis. 
Table 2 - Regression Results of the Effect of Self- and Cross-Citation (Top-Tier, Second-Tier and Specialized B2B Marketing Journals) on 2-year Impact Factor of IMM

\begin{tabular}{lccc}
\hline & $\begin{array}{c}\text { Unstandardized } \\
\text { Coefficients } \\
(p \text {-values })\end{array}$ & $\begin{array}{c}\text { Standardized } \\
\text { Coefficients }\end{array}$ & VIF \\
\hline Constant & -.08 & & \\
IMM self-citation rate & $(.72)$ & .10 & 1.56 \\
Top tier journals citation rate & 2.26 & .09 & 1.82 \\
Second tier and specialized journals citation rate & 79.29 & $.79^{* * *}$ & 1.46 \\
& $(.61)$ & & \\
\hline Observations & $(.00)$ & & \\
$R^{2}$ & & .805 & \\
Adjusted $R^{2}$ & & .751 & \\
${ }^{*} p<.10,{ }^{* *} p<.05,{ }^{* * * *} p<.01$ & & &
\end{tabular}

Multiple regression show that only second-tier and specialized B2B marketing journals citations have a significant positive effect on the 2 -year impact factor $(\beta=.79 ; \mathrm{p}<.00)$. Neither self-citation rates, nor citations in top-tier marketing journals, have any significant effect on the 2-year impact factor of IMM from 1999-2013. Overall, the model explained $75 \%$ of the variance in IMM's impact factor. All the variance inflation factors (VIFs) were less than 2, suggesting that multicollinearity was not an issue in the analysis. Given the self-citation patterns displayed in Figure 1, we also ran a regression analysis to test for a potential non-linear effect of selfcitation on impact factor. The results of the non-linear analysis were consistent with those seen in Table 2, suggesting that the effects obtained were stable and robust.

\section{Discussion}

The overall pattern of our results indicates that IMM self-citations followed a very shallow u-shaped pattern from 1999-2013 (See Figure 1). While the self-citation rates initially decrease, 
before starting to climb again, the IMM impact factor grew steadily over this period. The citations patterns show very low citation rates for IMM in the top-tier marketing journals (see Figure 2), indicating that IMM's share of knowledge imported by top marketing journals remains relatively small. The IMM impact factor seems to track citation rates in second-tier and specialized B2B marketing journals more closely.

Regressing the IMM impact factor over the years on the rates of self-citation, citation in toptier marketing journals, and citation rates in second-tier and specialized journals, indicates that self-citation and citation in top marketing journals had no significant effect on the impact factor of IMM (Table 2). For the period under examination, by far the biggest driver of IMM's 2-year impact factor were citations in second-tier and specialized journals. The proposed model explained 75\% of the variance in IMM impact factor of IMM from 1999-2013.

However, in order to tease out this effect even further, we conducted post-hoc analyses where we separated the citation rates in the second-tier journals from those in specialized B2B marketing journals. This post-hoc analysis presented in Figure 3 shows that when separated, the IMM citation pattern in second-tier marketing journals resemble those in top-tier marketing journals, with both tiers citing IMM at a fairly low rate relative to their overall levels of citations (i.e., knowledge imports). In fact, Figure 3 shows that the pattern of growth of IMM impact factor closely follows its citation rates in specialized B2B marketing journals (e.g., JBIM, $\mathrm{JBBM})^{5}$.

${ }^{5}$ Our database contained citation data for $J B B M$ and $J B I M$ for only 9 years, which leaves us with insufficient data points to estimate a new regression model with specialized B2B journals included as a separate predictor. 
Figure 3 - IMM Impact Factor, Self-Citation Rates, and Cross-Citation Rates in Top-Tier, Second-Tier, and Specialized B2B Marketing Journals (1999-2013)

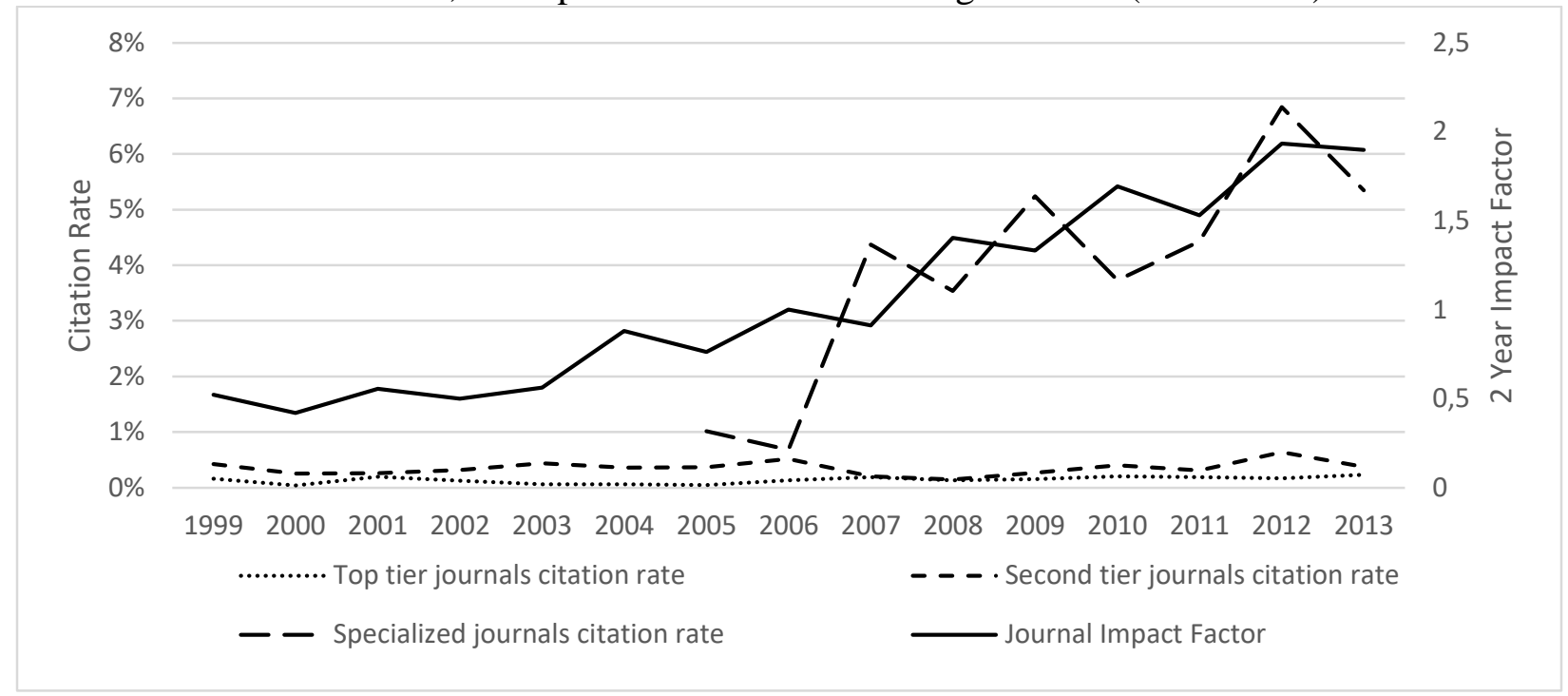

These findings are indicative of a larger, long-term trend of decreasing emphasis on B2B and industrial marketing topics in the top marketing journals over the last 15-20 years. Consistent with these findings, other researchers have also noted a decreasing emphasis on strategy research in general in top-tier marketing journals (Houston 2016). However, within the top-tier marketing journals, JAMS shows the strongest citation patterns for IMM in recent years, suggesting JAMS may have become the de-facto strategy \& B2B outlet of choice in the top-tier set. While JM shows the next best tendency to cite IMM in recent years, its in-bound citation rates from IMM are considerably weaker compared to JAMS.

In another follow-up post-hoc analysis, we went back to the larger database of 336 major business journals containing 5,390,245 citations from 116,750 articles, and extracted the Top 25 journals citing IMM from 1999 - 2013. Table 3 presents a list of these journals with year-byyear breakdown of how many times IMM was cited by each journal each year. A closer 
examination of Table 3 indicates three distinct clusters of journals (and domains) in which IMM is being cited heavily. The clusters on which IMM is making a significant impact correspond to:

- Second-tier marketing journals beyond the top 7-8 set, including the specialized B2B marketing journals (i.e., European Journal of Marketing, International Journal of Research in Marketing, Journal of Business to Business Marketing, Journal of Business and Industrial Marketing, Marketing Theory, Journal of International Marketing, International Marketing Review etc.);

- Journals in Technology-Innovation Management (TIM) domain (i.e., Journal of Product Innovation Management, International Journal of Technology Management, IEEE Transactions on Engineering Management, etc.); and

- Journals in operations management/logistics/supply chain management (OM/SCM) domains (i.e., Journal of Supply Chain Management, International Journal of Operations and Production Management, Journal of Purchasing and Supply Management, Journal of Operations Management, Journal of Physical Distribution and Logistics Management, International Journal of Logistics Management, etc.).

While at first the results related to second-tier marketing journals may seem to contradict the findings presented in Figure 3, it is important to note the distinction between the two analyses. The findings reported in Figure 3 pertain to the rate of citations in the top-tier and second-tier marketing journals. That is the fraction of the total citations or knowledge imported in these journals. The analysis presented in Table 3, by contrast, reports the raw numbers of actual IMM citations in these journals. These results together indicate that while IMM's share of knowledge cited in the top-tier (Rank 1-5) and second tier (Rank 5-10) marketing journals 
remains low, second tier marketing journals (outside the top 8 rankings) constitute some of the most frequent citers of IMM.

Thus while IMM's impact on the top 7-8 marketing journals remains light, it is a reflection of the decreasing emphasis being placed on marketing strategy research in general (and consequently B2B/industrial marketing research) in these journals during 1999-2013. However, IMM's impact factor has continued to grow at an impressive rate over this period. Much of this growth has come from sources other than self-citation. Our post-hoc analysis shows that IMM's appeal is growing, and it is having an ever increasing influence on the related domains of supply chain management (including operations management and logistics), and technology and innovation management.

These results attest to IMM's growing influence on fields and domains beyond marketing. Thus the partial vacuum created by a reduced emphasis on B2B/industrial marketing topics in top marketing journals is being filled by the second tier marketing journals (ranked 8 and beyond), and specialized journals in related fields of supply chain management, and technology and innovation management, which show some of the highest citations of research published in IMM from 1999-2013. The results concerning IMM's influence on fields outside the marketing discipline, in fact, corroborate the conclusions of Touzani and Moussa (2010), who ranked marketing journals using Google Scholar data. They noted that IMM was one of the journals that ranked very high using their methodology, and speculated that one reason for this finding was the popularity of IMM among academics from other disciplines such as strategy, innovation, management, and product development. Our results show that much of the increase in IMM cites is in journals that correspond precisely to these research disciplines (e.g., Journal of Product Innovation Management, International Journal of Technology Management, IEEE 
Transactions on Engineering Management) or to related disciplines such as supply chain management and operations (e.g., Journal of Supply Chain Management, Journal of Purchasing and Supply Management, Journal of Operations Management).

\section{Conclusions}

This study presents a citation analysis of the impact of Industrial Marketing Management on the marketing literature. We assessed the impact of IMM on top-tier, second-tier, and specialized B2B marketing journals, and in post hoc analysis, increased the scope of analysis to include journals in related disciplines as well. The period of data availability corresponded closely to the years during which Peter LaPlaca guided the journal, so the results present a form of external validation of the impact of IMM on research in B2B marketing and elsewhere.

The results showed relatively low citation patterns for IMM in some of the top-tier marketing journals - not an unexpected finding, given the relatively lower emphasis on marketing strategy research in recent years among the top marketing journals (Houston 2016). Nevertheless, one first-tier journal, Journal of the Academy of Marketing Science, shows strong citation patterns, indicating that it may be the top-tier journal most frequently (or most successfully) targeted by B2B marketing researchers. IMM has retained a strong and growing

presence in the second-tier and specialized B2B marketing journals, suggesting that articles published in IMM are viewed as highly influential by authors working in B2B marketing research and related streams. The post hoc analysis showed IMM's influence increasing in other fields as well, as judging by high citation numbers in innovation and product development journals such as Journal of Product Innovation Management, and operations and supply chain management journals such as Journal of Operations Management. The impressive citation 
counts of IMM over the years in B2B marketing and general marketing publications, as well as in related disciplines such as innovation, indicate that, under the thoughtful stewardship of Peter LaPlaca, Industrial Marketing Management has consistently grown in quality, relevance, and influence on ever larger numbers of business scholars. IMM has been the leading journal for published research in $\mathrm{B} 2 \mathrm{~B}$ and industrial marketing management and strategy for many years, and thanks to the sure-handed and insightful leadership and guidance of Editor-in-Chief Peter LaPlaca, is poised to maintain this position for years to come. 
Table 3 - Journals Citing IMM Highest Number of Times from 1999-2013

\begin{tabular}{|c|c|c|c|c|c|c|c|c|c|c|c|c|c|c|c|c|}
\hline \multirow[b]{3}{*}{ Citing journal } & \multirow{2}{*}{\multicolumn{16}{|c|}{ Year }} \\
\hline & & & & & & & & & & & & & & & & \\
\hline & $\hat{\mathrm{g}}$ & ষ্̀ે & క్సิ & ธิ๊ & ڤ్̀ે & țָે & ثิે & క్రે & ثิ & ڤ్̀ે & ڤ్̀ે & 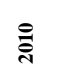 & $\bar{\Xi}$ & ัิ & 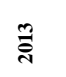 & ङ \\
\hline $\begin{array}{l}\text { INDUSTRIAL MARKETING MANAGEMENT } \\
\end{array}$ & 119 & 106 & 119 & 148 & 123 & 146 & 137 & 121 & 289 & 310 & 231 & 736 & 677 & 950 & 1085 & 5297 \\
\hline JOURNAL OF BUSINESS \& INDUSTRIAL MARKETING & & & & & & & & & 109 & 99 & 139 & 111 & 146 & 234 & 182 & 1020 \\
\hline JOURNAL OF BUSINESS RESEARCH & 14 & 9 & 6 & 27 & 30 & 35 & 35 & 52 & 24 & 15 & 17 & 48 & 49 & 151 & 77 & 589 \\
\hline EUROPEAN JOURNAL OF MARKETING & & & & & & & 33 & 81 & 33 & 38 & 27 & 65 & 52 & 41 & 51 & 421 \\
\hline JOURNAL OF BUSINESS-TO-BUSINESS MARKETING & & & & & & & 26 & 20 & 17 & 29 & 44 & 35 & 56 & 57 & 63 & 347 \\
\hline JOURNAL OF PRODUCT INNOVATION MANAGEMENT & 17 & 14 & 14 & 7 & 16 & 9 & 12 & 14 & 10 & 7 & 25 & 36 & 32 & 62 & 64 & 339 \\
\hline SUPPLY CHAIN MANAGEMENT-AN INTERNATIONAL JOURNAL & & & & & 19 & 11 & 29 & 19 & 20 & 53 & 18 & 42 & 18 & 24 & 46 & 299 \\
\hline INTERNATIONAL JOURNAL OF OPERATIONS \& PRODUCTION MANAGEMENT & 2 & 8 & 18 & 4 & 5 & 11 & 20 & 28 & 15 & 36 & 28 & 21 & 18 & 31 & 39 & 284 \\
\hline TECHNOVATION & 2 & 5 & 2 & 1 & 1 & 4 & 25 & 24 & 7 & 30 & 21 & 11 & 11 & 25 & 6 & 175 \\
\hline INTERNATIONAL MARKETING REVIEW & 7 & 1 & 7 & 3 & 12 & 9 & 6 & 10 & 4 & 19 & 6 & 30 & 7 & 13 & 34 & 168 \\
\hline JOURNAL OF THE ACADEMY OF MARKETING SCIENCE & 7 & 1 & 12 & 4 & 1 & 2 & & 8 & 18 & 8 & 14 & 29 & 24 & 16 & 20 & 164 \\
\hline JOURNAL OF INTERNATIONAL MARKETING & 6 & 2 & 7 & 5 & 3 & 4 & 9 & 27 & 2 & 4 & 5 & 40 & 11 & 25 & 13 & 163 \\
\hline JOURNAL OF PURCHASING AND SUPPLY MANAGEMENT & & & & & & & & & & & 28 & 37 & 33 & 46 & 12 & 156 \\
\hline JOURNAL OF BUSINESS ETHICS & 4 & 5 & 3 & 13 & 6 & 5 & 2 & 4 & 5 & 9 & 12 & 37 & 21 & 8 & 19 & 153 \\
\hline JOURNAL OF OPERATIONS MANAGEMENT & & 3 & 1 & 7 & 1 & 2 & 2 & 11 & 18 & 7 & 2 & 25 & 31 & 22 & 18 & 150 \\
\hline JOURNAL OF SERVICE MANAGEMENT & & & & & & & & & & & 15 & 50 & 29 & 39 & 14 & 147 \\
\hline INTERNATIONAL JOURNAL OF TECHNOLOGY MANAGEMENT & 10 & 3 & 7 & 6 & 8 & 21 & 3 & 3 & 6 & 13 & 4 & 16 & 13 & 4 & 13 & 130 \\
\hline $\begin{array}{l}\text { INTERNATIONAL JOURNAL OF PHYSICAL DISTRIBUTION \& LOGISTICS } \\
\text { MANAGEMENT }\end{array}$ & & & & & & & & & & 18 & 13 & 22 & 18 & 24 & 24 & 119 \\
\hline INTERNATIONAL BUSINESS REVIEW & & & & & & & 4 & 5 & & 5 & 12 & 5 & 9 & 20 & 45 & 105 \\
\hline JOURNAL OF SUPPLY CHAIN MANAGEMENT & & & & & & & & & & 16 & 15 & 5 & 20 & 18 & 24 & 98 \\
\hline IEEE TRANSACTIONS ON ENGINEERING MANAGEMENT & & 3 & 1 & 6 & & 5 & 19 & 8 & 8 & 4 & 9 & 8 & 10 & 10 & 4 & 95 \\
\hline INTERNATIONAL JOURNAL OF LOGISTICS MANAGEMENT & & & & & & & & & & 5 & 14 & 30 & 10 & 15 & 20 & 94 \\
\hline JOURNAL OF WORLD BUSINESS & 1 & 4 & & & & 9 & 1 & 1 & 2 & 8 & 5 & 5 & 29 & 10 & 14 & 89 \\
\hline INTERNATIONAL JOURNAL OF RESEARCH IN MARKETING & 4 & & 4 & 3 & 2 & 1 & 1 & 20 & & 3 & 8 & 28 & 7 & 3 & 3 & 87 \\
\hline MARKETING THEORY & & & & & & & & & & 11 & 10 & 8 & 7 & 7 & 44 & 87 \\
\hline
\end{tabular}




\section{References}

Calabretta, Giulia, Boris Durisin, and Marco Ogliengo (2011). Uncovering the intellectual structure of research in business ethics: A journey through the history, the classics, and the pillars of Journal of Business Ethics. Journal of Business Ethics, 104(4), 499-524.

Chintagunta, Pradeep, Dominique Hanssens, John R. Hauser, Jagmohan S. Raju, Kannan Srinivasan, and Richard Staelin (2013). Marketing Science: A strategic review. Marketing Science, 32(1), 4-7.

Clark, Terry, Thomas Martin Key, Monica Hodis, and Daniel Rajaratnam (2014). The intellectual ecology of mainstream marketing research: An inquiry into the place of marketing in the family of business disciplines. Journal of the Academy Marketing Science, 42(3) 223-241.

Guidry, Julie A., Brandi N. G. Hollier, Linda Johnson, John R. Tanner, and Christiane Veltsos (2004). Surveying the cites: A ranking of marketing journals using citation analysis. Marketing Education Review, 14(1), 45-59.

Houston, Mark (2016). Is strategy a dirty word? Journal of the Academy of Marketing Science, 44(5), 557-561. 
Huber, Joel, Wagner Kamakura, and Carl F. Mela (2014). A topical history of JMR. Journal of Marketing Research, 51(1), 84-91.

Hustad, Thomas P. (2013). PDMA History, Publications, and Developing a Future Research Agenda: Appreciating Our PDMA Accomplishments - Celebrating People, Lasting Friendships and Our Collective Accomplishments. Xlibris..

Shafiq, Muhammad (2013). Thinking inside the box? Intellectual structure of the knowledge base of innovation research (1988-2008). Strategic Management Journal, 34(1), 62-93.

Schrock, Wyatt A., Yanhui Zhao, Douglas E. Hughes, and Keith A. Richards (2016). JPSSM since the beginning: intellectual cornerstones, knowledge structure, and thematic developments. Journal of Personal Selling \& Sales Management, 36(4), 321-343.

Touzani, M. and S. Moussa (2010). Ranking marketing journals using the search engine Google Scholar. Marketing Education Review, 20(3), 229-247. 